\title{
Bacteriological Surveillance of Ambulance Vehicles from a Tertiary Care Hospital of North India
}

\author{
Shiwani Sharma ${ }^{1, \odot}$ Priya Datta ${ }^{2}$ Varsha Gupta ${ }^{3, \odot}$ \\ ${ }^{1}$ Department of Microbiology, Gian Sagar Medical College, Rajpura, \\ Punjab, India \\ 2Department of Medical Parasitology, PGIMER, Chandigarh, India \\ ${ }^{3}$ Department of Microbiology, Government Medical College \\ Hospital, Chandigarh, India
}

\author{
Dipanshu Vasesi $^{3} \quad$ Jagdish Chander ${ }^{3}$
}

\author{
Address for correspondence Priya Datta, MD, Department \\ of Medical Parasitology, PGIMER, Chandigarh 160012, India \\ (e-mail: drpriyadatta@hotmail.com).
}

\begin{abstract}
Keywords

- ambulance

- disinfection

- infectious microorganisms

- multidrug resistant

Objective An ambulance is a medically equipped vehicle which is used in case of any medical emergency for the transport of patients to treatment facilities. The ambulances help in the transportation of thousands of patients per year, and such patients may carry infectious microorganisms which pose a major threat to the treatment of such patients. In this study, we analyzed the extent of bacterial contamination in our ambulance vehicles and measured the degree of antimicrobial resistance among isolated pathogens.

Material and Method This study included five ambulances of our tertiary care hospital and different random sites were swabbed in each vehicle. These were selected based on their well-known high frequency of contact by emergency personnel and patients. Swabs were inserted into sterile test tubes containing normal saline and immediately transferred to our microbiology laboratory to identify bacterial contaminants utilizing standard microbiological procedures.

Result A total of 198 swab samples were collected from all the five ambulances, out of which $170(85.8 \%)$ swabs were sterile and $28(14.2 \%)$ swabs yielded potentially pathogenic bacterial isolates. The highest contamination rate with pathogenic bacteria was detected in the oxygen flow meter knob $(60 \%)$, suction machine tubing (60\%), and stethoscope (40\%). Staphylococcus aureus (32\%) was the most frequently detected microorganism.

Conclusion Our study showed low prevalence of bacterial contamination in ambulances because of good infection control policy of our hospital, however, some areas still need improvement and require proper standard operating procedures of disinfection policies of these emergency vehicles.
\end{abstract}

\section{Introduction}

An ambulance is a medically equipped vehicle which is used in case of a medical emergency by Emergency Medical Services (EMS) which transport patients to treatment facilities, such as a hospital, and transport paramedics and other first responders to the place of emergency. ${ }^{1}$ Ambulances were first introduced for emergency transport by the Spanish in 1487, and for civilians this emergency service was started during $1830 .^{2}$ published online

June 18, 2021
DOI https://doi.org/

10.1055/s-0041-1730848

ISSN $0974-2727$ (c) 2021. The Indian Association of Laboratory Physicians.

This is an open access article published by Thieme under the terms of the Creative Commons Attribution-NonDerivative-NonCommercial-License, permitting copying and reproduction so long as the original work is given appropriate credit. Contents may not be used for commercial purposes, or adapted, remixed, transformed or built upon. (https://creativecommons.org/licenses/by-nc-nd/4.0/).

Thieme Medical and Scientific Publishers Pvt. Ltd. A-12, 2nd Floor, Sector 2, Noida-201301 UP, India 
The ambulance services available generally fall into one of these three categories: basic life support (BLS), advanced life support (ALS), and in some cases, intermediate life support (ILS). The ALS ambulances are available with cardiac monitor and defibrillator in addition to the basic provisions of a BLS ambulance. ${ }^{3}$ Ambulances help thousands of patients per year, and such patients carrying an infectious microorganism may cough, vomit, urinate, excrete, or spill body fluid and blood during hospital transport .These infectious microorganisms can be multidrug resistant (MDR) or extensively drug resistant (XDR), and may get deposited on the surfaces of the ambulance as a fomite until they are inhaled, ingested, touched, or inoculated into subsequent patient, passenger, and health-care worker. As most ambulances carry patients from road traffic accidents, trauma cases, and emergency cases, MDR or XDR pathogens are major threats in the treatment of such patients. Thus, determining the risks should facilitate the advancement of best practices to enhance infection control of routine outbreaks and during a major emergency such as a disease pandemic.

Although the use of universal precautions, ${ }^{4}$ personal protective gear, ${ }^{5}$ and disposable equipment reduces risks of infection to patients and care providers, the ambulance remains the most vulnerable to bacterial contamination from biological secretions and potential pathogens. So, it is very important that after each mission, each ambulance vehicle must be cleaned and decontaminated to be ready for use for the next mission. Effective cleaning protocols like the use of disinfectants (hypochlorite, alcohol, hydrogen peroxide, quaternary ammonium compounds, and phenolic compound) for this emergency medical environment should be followed to avoid any transmission of pathogenic microorganisms that represent a potential risk of infection for patients or even the accompanying emergency medical professionals.

In this study, we analyzed the extent of bacterial contamination in our ambulance vehicles and measured the degree of antimicrobial resistance among isolated pathogens. This study is also important because numerous studies have assessed hospital-acquired infections (HAIs) and its control but only few literatures exist regarding the probability of transmission of infection through ambulances.

\section{Materials and Methods}

This study was conducted in our 750 bedded tertiary care hospital in north India region. A total of five ambulances were included in our study. All the ambulances in this study were BLS equipped. No prior information was given to the ambulance crew about the sampling. The number of times a vehicle is used in a day to transfer patients is difficult to predict and types of patients to be transferred were not defined for ambulance. There is a cleaning and disinfection roster in place; the roster is such that each cleaning and disinfection exercise gets approximately 3 to 4 hours for the disinfection to be most effective. Cleaning and disinfection is done depending on the number of times the vehicle is used in a day; however, priority is given to patient transfer and the disinfection is put on hold for the next time slot as per the roster. Different random sites were swabbed in each vehicle and these were selected based on their well-known high frequency of contact by emergency personnel and patients. These areas were as follows: door handle, patient stretcher mattress, handle of stretcher, backrest of the patient stretcher, oxygen cylinder, oxygen flow meter knob, sink, mouth of ambubag, walls of ambulance, exhaust fan, portable ventilator screen, syringe pump, suction machine tubing, oropharyngeal airway (two in number), AC vent, wheelchair, blood pressure cuff, stethoscope, emergency personnel seat, backrest of relative chair, cervical collar, and steering wheel. These surfaces were swabbed with sterile cotton swabs moistened with sterile $0.9 \% \mathrm{NaCl}$ solution. During the sampling process, swabs were passed over the entire sampling point and rotated to collect as much material as possible. Swabs were inserted into sterile test tubes containing normal saline to avoid desiccation during transport. Then the swabs were immediately transferred to the laboratory to identify bacterial contaminants utilizing standard microbiological procedures.

Upon arrival at the microbiology laboratory, swabs were immediately transferred into brain heart infusion broth and incubated for 18 to 24 hours at $37^{\circ} \mathrm{C}$. Thereafter, the swabs were plated onto $5 \%$ Sheep Blood agar, mannitol salt agar, and MacConkey's agar and identified by standard biochemical tests. ${ }^{6}$ Controls of sterile cotton swab and sterile cotton swabs moistened with $0.9 \% \mathrm{NaCl}$ solution were also put to sterility check. All positive bacterial cultures were identified standard microbiological procedures. The bacterial susceptibility was done according to CLSI (Clinical and Laboratory Standards Institute) 2019 criteria. Additionally, Enterobacteriaceae were tested for ESBL (extended spectrum $\beta$ lactamases) according to CLSI. MRSA (methicillin-resistant Staphylococcus aureus) was identified using cefoxitin disk according to CLSI criteria.?

\section{Results}

A total of 198 swab samples were collected from all the five ambulances, out of which 170 (85.8\%) swabs were sterile and 28 (14.2\%) swabs yielded potentially pathogenic bacterial isolates as shown in - Fig. 1 (bar diagram). The highest contamination rate with pathogenic bacteria was detected in oxygen flow meter knob (60\%), suction machine tubing (60\%), and

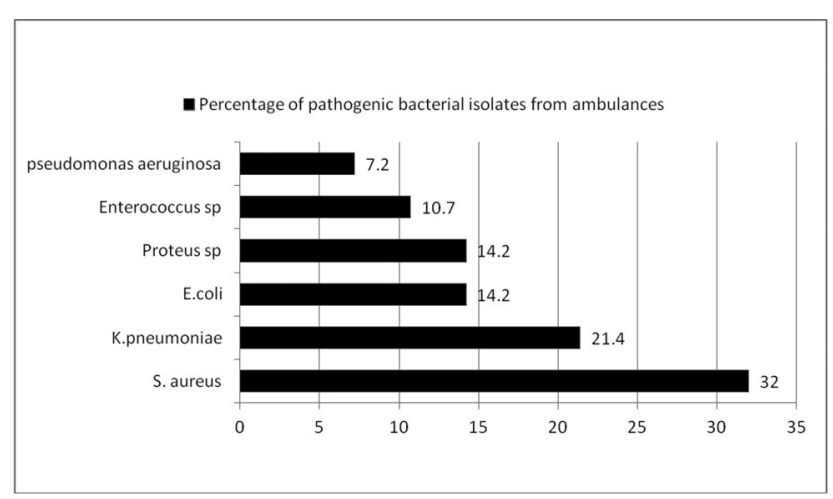

Fig. 1 Bar diagram showing percentage of bacterial isolates from five ambulance vehicles. 
stethoscope (40\%). Staphylococcus aureus (32\%) was the most frequently detected microorganism followed by Klebsiella spp (21.4\%), Escherichia coli (14.2\%), Proteus spp (14.2\%), Enterococcus spp (10.7\%), and Pseudomonas aeruginosa (7.2). MRSA was seen in $22 \%$ of the total Staphylococcus aureus, as shown in - Table 1. Higher resistance to $S$. aureus was seen in penicillin (55\%), gentamicin (55\%), and erythromycin (66.7\%). The resistance rate was lower for ciprofloxacin, doxycycline, clindamycin, and cotrimoxazole (22-33\%), whereas none of the strains of isolated Staphylococcus aureus showed resistance to linezolid and teicoplanin. Higher resistance was seen in Enterococcus species to penicillin, ciprofloxacin, erythromycin, and gentamicin (66-100\%), as in - Table 2. None the strains of Enterococcus species showed resistance to vancomycin, whereas in gram-negative bacteria Klebsiella spp (33\%), E. coli (50\%), and Proteus spp (25\%) were ESBL producers and showed sensitivity to imipenem, as shown in - Table 3. ESBL was detected in Klebsiella species (16.7\%), Proteus spp (25\%), and E. coli (25\%) by initial phenotypic screening testing and further confirmed as ESBL producers by confirmatory test, i.e., phenotypic confirmatory combined-disk test.

\section{Discussion}

Ambulance vehicles are an integral part of EMS. While designing an EMS, the essential decision in prehospital care is whether the patient should be immediately taken to the hospital, or advanced care resources are taken to the patient.

Table 1 Distribution of various bacterial isolates from ambulance sites

\begin{tabular}{|c|c|c|c|c|c|c|c|}
\hline S. no & $\begin{array}{l}\text { Ambulance } \\
\text { site }\end{array}$ & $\begin{array}{l}\text { Staphylococcus } \\
\text { aureus }(n=9)\end{array}$ & $\begin{array}{l}\text { Klebsiella } \\
\text { spp. }(n=6)\end{array}$ & $\begin{array}{l}\text { Escherichia } \\
\text { coli }(n=4)\end{array}$ & $\begin{array}{l}\text { Proteus spp } \\
(n=4)\end{array}$ & $\begin{array}{l}\text { Enterococcus } \\
\operatorname{spp}(n=3)\end{array}$ & $\begin{array}{l}\text { Pseudomonas } \\
\text { aeruginosa }(n=2)\end{array}$ \\
\hline 1. & $\begin{array}{l}\text { Patient } \\
\text { stretcher } \\
\text { mattress }\end{array}$ & - & 1 & - & - & 1 & - \\
\hline 2. & Door handle & 1 & - & - & - & - & - \\
\hline 3. & $\begin{array}{l}\text { Handle of } \\
\text { stretcher }\end{array}$ & 1 & - & - & - & 1 & - \\
\hline 4. & $\begin{array}{l}\text { Backrest of } \\
\text { the patient } \\
\text { stretcher }\end{array}$ & - & - & - & 1 & - & - \\
\hline 5. & $\begin{array}{l}\text { Oxygen } \\
\text { cylinder }\end{array}$ & - & - & - & - & - & - \\
\hline 6. & $\begin{array}{l}\text { Oxygen flow } \\
\text { meter knob }\end{array}$ & 2 & 1 & 1 & - & - & - \\
\hline 7. & Sink & - & - & - & 1 & - & 1 \\
\hline 8. & $\begin{array}{l}\text { Mouth of } \\
\text { ambubag }\end{array}$ & - & - & - & - & - & - \\
\hline 9. & $\begin{array}{l}\text { Walls of } \\
\text { ambulance }\end{array}$ & - & - & 1 & - & 1 & - \\
\hline 10. & $\begin{array}{l}\text { Portable venti- } \\
\text { lator screen }\end{array}$ & - & - & - & - & - & - \\
\hline 11. & Syringe pump & - & - & 1 & - & - & - \\
\hline 12. & $\begin{array}{l}\text { Suction } \\
\text { machine tubing }\end{array}$ & 2 & 1 & - & - & - & 1 \\
\hline 13. & $\begin{array}{l}\text { Oropharyngeal } \\
\text { airway (two in } \\
\text { number) }\end{array}$ & - & - & - & - & - & - \\
\hline 14. & $A C$ vent & - & - & -1 & 1 & - & - \\
\hline 15. & Wheelchair & - & 1 & - & - & - & - \\
\hline 16. & $\begin{array}{l}\text { Blood pressure } \\
\text { cuff }\end{array}$ & 1 & - & - & - & - & - \\
\hline 17. & Stethoscope & 2 & 1 & - & - & - & - \\
\hline 18. & $\begin{array}{l}\text { Emergency } \\
\text { personnel seat, }\end{array}$ & - & - & - & 1 & - & - \\
\hline 19. & $\begin{array}{l}\text { Backrest of } \\
\text { relative chair }\end{array}$ & - & - & - & - & - & - \\
\hline 20. & Cervical collar & - & - & - & - & - & - \\
\hline 21. & Steering wheel & - & - & - & - & - & - \\
\hline 22. & Exhaust fan & - & 1 & - & - & - & - \\
\hline
\end{tabular}


Table 2 Antimicrobial resistance pattern (in percentage) of gram-positive bacterial isolates

\begin{tabular}{|l|l|l|l|l|l|l|l|l|l|l|l|}
\hline & $\mathbf{P}$ & Cx & Cip & Er & Cd & Cot & Dox & Lz & Va & Tei & Gen \\
\hline S. aureus & $55.6 \%$ & $22 \%$ & $22 \%$ & $66.7 \%$ & $33.3 \%$ & $33.3 \%$ & $22.2 \%$ & $0 \%$ & - & $0 \%$ & $55.6 \%$ \\
\hline $\begin{array}{l}\text { Enterococcus } \\
\text { spp. }\end{array}$ & $66.7 \%$ & - & $66.7 \%$ & $100 \%$ & $33.3 \%$ & $0 \%$ & $33.3 \%$ & $0 \%$ & $0 \%$ & $0 \%$ & $66.7 \%$ \\
\hline
\end{tabular}

Abbreviations: Cd, clindamycin; Cip, ciprofloxacin; Cot, cotrimaxazole; Cx, cefoxitin; Dox, doxycycline; Er, erythromycin; Gen, gentamicin; Lz, linezolid; P, penicillin; tei, teicoplanin; Va, vancomycin.

Table 3 Antimicrobial resistance pattern (in percentages) of gram-negative bacterial isolates

\begin{tabular}{|l|l|l|l|l|l|l|l|l|l|l|l|}
\hline & Amc & Caz & Cef & Cpm & Ak & Cip & Tet & Pit & Imp & Az & Pb/co \\
\hline Klebsiella spp. & $33 \%$ & $16.7 \%$ & $16.7 \%$ & $16.7 \%$ & $0 \%$ & $33.3 \%$ & $66.7 \%$ & $0 \%$ & $16.7 \%$ & - & $0 \%$ \\
\hline $\begin{array}{l}\text { Escherichia } \\
\text { coli }\end{array}$ & $50 \%$ & $25 \%$ & $25 \%$ & $25 \%$ & $0 \%$ & $25 \%$ & $50 \%$ & $0 \%$ & $0 \%$ & - & $0 \%$ \\
\hline Proteus spp. & $25 \%$ & $25 \%$ & $25 \%$ & $25 \%$ & $0 \%$ & $50 \%$ & $25 \%$ & $0 \%$ & $0 \%$ & - & $100 \%$ \\
\hline $\begin{array}{l}\text { Pseudomonas } \\
\text { aeruginosa }\end{array}$ & - & $0 \%$ & - & - & $0 \%$ & $0 \%$ & - & $0 \%$ & $0 \%$ & $0 \%$ & - \\
\hline
\end{tabular}

Abbreviations: Ak, amikacin; Amc, amoxicillin clavulanic acid; Az, aztreonam; Caz, ceftazidime; Cef, cefotaxime; Cip, ciprofloxacin; Cpm, cefepime; Imp, imipenem; Pit, piperacillin-/tazobactam; Pb/co, polymyxin/colistin; Tet, tetracycline.

Thus, minimal time is spent in providing prehospital care, (i.e., ensure airway, breathing, and circulation $[A B C]$, external bleeding control, and endotracheal intubation) and the patient is transported as fast as possible from the site of emergency to health care facility. However, ambulance also acts as a potential source of nosocomial infections caused by various pathogenic microorganisms carried by the patients which in turn are source of infections to health care workers, other staff, and relatives of the patients. Some of the pathogen are MDR and extremely drug resistant (XDR) and can cause serious infections and diseases. ${ }^{8}$ The presence of pathogenic organisms in rescue vehicles is also very dangerous especially for severely ill patients and when transporting immunocompromised patients who are more prone to infections. These microorganisms can be detected not only in the interior of ambulances but also on the emergency services equipment. Therefore, microbiological evaluation of ambulance vehicles is an essential infection control step that must be considered to reduce the risk and timely interventions of such infections. Currently, no such study has reported the prevalence of clinically important pathogens and their antimicrobial susceptibility in the ambulances. This study is the first work in India to describe the level microbial populations in ambulances and their role as a major source of HAIs.

The presence of pathogenic microorganism in various sites of ambulance is expected because they are touched frequently with the hands and come in contact with patient and patient's body secretions, i.e., pus, blood, urine, stool, and other body fluids. Another reason of bacterial contamination can be failure in effective cleaning and disinfection of the vehicles, lack of consistency in frequency of cleaning, and faultier method of cleaning.

In our study, we have isolated 28 (14.2\%) pathogenic isolates. The most common bacteria isolated was $S$. aureus 9 (32\%) which is similar to other studies by Brown et $\mathrm{al}^{9}$ and Orellana et $\mathrm{al}^{10}$ which depicted $S$. aureus as an important opportunistic bacterial pathogen frequently identified in ambulances in Southern Maine and in Ohio, respectively. Two (7\%) isolates in our study were detected as MRSA, which is similar to a German study ${ }^{11}$ that reported comparatively lower MRSA contamination rates of ambulances (7-9\%). However, a study by Datta et $\mathrm{a}^{12}$ done earlier in our hospital showed the prevalence of MRSA as 35\%. Another study by Eibicht et $\mathrm{a}^{13}$ showed MRSA contamination of ambulance cars after short-term transport of MRSA-colonized patients is restricted to the patient stretcher. Another study showed approximately $50 \%$ of ambulances to be contaminated by MRSA which is contrary to our study. ${ }^{14}$

A study by El-Mokhtar and Hetta ${ }^{15}$ showed similar results like our study in which $S$. aureus were the most frequently detected microorganisms from the collection sites followed by K. pneumoniae and E. coli. Another study by Nigam and Cutter $^{16}$ showed gram-negative coliforms of a variety of genera including Enterobacter, Klebsiella, and Escherichia commonly detected in the ambulances, suggestive of contamination with fecal or soil matter. The highest contamination rate with pathogenic bacteria was detected from oxygen flow meter knob (60\%) similar to study by Alrazeeni et al, ${ }^{8}$ suction machine tubing (60\%), and stethoscope (40\%) which is similar to an Egyptian study. ${ }^{15}$ Another work by Merlin et al also depicted that medical devices such as stethoscopes showed a high rate of Staphylococcus (MRSA) contamination. ${ }^{17}$ The reason for high prevalence of $S$. aureus could be its presence in the nose of approximately $30 \%$ of healthy adults and on the skin of approximately $20 \%$ and by frequent and repeated touching of the surfaces of ambulance and other equipment with hands it can be easily transferred. The percentages are higher for people who are patients in a hospital or who work there. Studies also showed that a recurrent route of infection transmission occurred due to touching of contaminated surfaces or medical equipment by paramedic's gloved or ungloved hands and by patient's contact with contaminated surfaces or items..$^{18}$ There are studies which highlighted the role of EMS worker sanitation as an important contributing factor to 
HAI transmission and health care uniforms have been implicated as a fomite for HAI transmission in hospitals. ${ }^{19,20}$

The identification of any pathogenic microorganism in ambulance raises special concerns since ambulance staff may get infected and these pathogens can also be transmitted to new patients, or relatives who may travel along with the patient to the hospital. Thus, it is important to understand that ambulances can be a potential source of contamination, and therefore, more intense infection control mechanisms and disinfection practices need to be employed. There should be stringent disinfection protocols including initial mopping or wiping which can bring down the microbial loads from the surfaces contaminated with gross contaminants like blood, dust, or dirt, any body fluids, etc., to be followed by cleaning and disinfection using various disinfectants like 1 to 10\% hypochlorite solution, 70 to $80 \%$ alcohol, glutaraldehyde, quaternary ammonium chloride, etc. ${ }^{16}$ As per HICC policy of our hospital, after every use of any equipment/instrument, ambulance is cleaned with disinfectant (70\% ethanol or hypochlorite solution). This is the reason that in our study no bacteria were isolated from ambubags. However, growth of bacteria from other sites in our study could be due to the presence of organic matter and formation of bacterial biofilm which may reduce the efficacy of terminal cleaning procedures as it enables bacteria to resist disinfectants and survive in the environment for a long time. ${ }^{21}$

The hospital infection control programs being followed at most of the hospitals do not widely focus on ambulance disinfection, which should ideally be of concern as part of public health administration. Ambulance staff should be properly trained in various disinfection protocols including good hand washing practices, proper donning and doffing of personal protective equipment.

The absence of any existing data on prevalence of pathogenic microorganisms in ambulances especially from the developing countries adds to the importance of conducting and publishing this study. Although there are thousands of published studies on HAIs but only a few have looked into the prevalence of pathogenic microorganisms and effectiveness of cleaning protocols and practices in the EMS structure of the developing countries. Prevention of HAIs needs to be considered on high priority especially in developing countries like India where the prevalence of these infections is up to three times higher as compared with other countries. Cleaning of vehicles, equipment, and supplies regularly and on time-tabled cleaning schedules apart from disinfection after every transport should be the basic protocol to prevent such spread of bacterial contamination specially with drug-resistant bacteria in prehospital care settings. ${ }^{22}$

\section{Conclusion}

Our study provides evidence that ambulances represent a source of prehospital bacterial contamination. Though the prevalence is very low because of good infection control policy adopted by our hospital, ambulances are religiously disinfected after every visit. However some areas still need improvement and require proper standard operating procedures of disinfection policies of these emergency vehicles and the equipment installed in it.

\section{Conflict of Interest}

None.

\section{References}

1 Skinner HA, "The Origin of Medical Terms". Baltimore: Williams \& Wilkins; 1949

2 Barkley KT, The Ambulance. New York: Exposition Press; 1990

3 National Health Systems Resource Centre (NHSRC). Study of Emergency Response Service-EMRI Model. Report by the Ministry of Health \& Family Welfare, Government of India; 2009

4 Srinivasan A, Song X, Ross T, Merz W, Brower R, Perl TM. A prospective study to determine whether cover gowns in addition to gloves decrease nosocomial transmission of vancomycin-resistant enterococci in an intensive care unit. Infect Control Hosp Epidemiol 2002;23(8):424-428

5 Occupational Health and Safety Administration. Personal Protective Equipment. Document\#3151. Available at: http:// www.osha.gov/index.html. Accessed October 20, 2005

6 Collee JG, Miles RS, Watt B, Tests for the identification of bacteria. In: Collee JG, Fraser AG, Marmion BP, Simmons A, eds. Mackie \& MacCartney Practical Medical Microbiology. 14th ed. London: Churchill Livingstone; 1996 151-179

7 Clinical and Laboratory Standards Institute, Performance Standards for Antimicrobial Susceptibility Testing: Twenty First Informational Supplement M100-S21. Wayne, PA: CLSI; 2019

8 Alrazeeni D, Al Sufi MS, Sufi A. Nosocomial infections in ambulances and effectiveness of ambulance fumigation techniques in Saudi Arabia. Phase I study. Saudi Med J 2014;35(11):1354-1360

9 Brown R, Minnon J, Schneider S, Vaughn J. Prevalence of methicillin-resistant Staphylococcus aureus in ambulances in southern Maine. Prehosp Emerg Care 2010;14(2):176-181

10 Orellana RC, Hoet AE, Bell C, et al. Methicillin-resistant Staphylococcus aureus in Ohio EMS providers: a statewide cross-sectional study. Prehosp Emerg Care 2016;20(2):184-190

11 Vikke HS, Giebner M. POSAiDA: presence of Staphylococcus aureus/MRSA and Enterococcus/VRE in Danish ambulances. A cross-sectional study. BMC Res Notes 2016;9:194

12 Datta P, Gulati N, Singla N, et al. Evaluation of various methods for the detection of methicillin-resistant Staphylococcus aureus strains and susceptibility patterns. J Med Microbiol 2011;60(Pt 11) :1613-1616

13 Eibicht SJ, Vogel U; BEibicht SJ. Methicillin-resistant Staphylococcus aureus (MRSA) contamination of ambulance cars after short term transport of MRSA-colonised patients is restricted to the stretcher. J Hosp Infect 2011;78(3):221-225

14 Roline CE, Crumpecker C, Dunn TM. Can methicillin-resistant Staphylococcus aureus be found in an ambulance fleet? Prehosp Emerg Care 2007;11(2):241-244

15 El-Mokhtar MA, Hetta HF. Ambulance vehicles as a source of multidrug-resistant infections: a multicenter study in Assiut City, Egypt. Infect Drug Resist 2018;11:587-594

16 Nigam Y, Cutter J. A preliminary investigation into bacterial contamination of Welsh emergency ambulances. Emerg Med J 2003;20(5):479-482

17 Merlin MA, Wong ML, Pryor PW, et al. Prevalence of methicillin-resistant Staphylococcus aureus on the stethoscopes of emergency medical services providers. Prehosp Emerg Care 2009;13(1):71-74

18 Muto CA, Jernigan JA, Ostrowsky BE, et al. SHEA. SHEA guideline for preventing nosocomial transmission of multidrug-resistant strains of Staphylococcus aureus and enterococcus. Infect Control Hosp Epidemiol 2003;24(5):362-386 
19 Treakle AM, Thom KA, Furuno JP, Strauss SM, Harris AD, Perencevich EN. Bacterial contamination of health care workers' white coats. Am J Infect Control 2009;37(2):101-105

20 Wiener-Well Y, Galuty M, Rudensky B, Schlesinger Y, Attias D, Yinnon AM. Nursing and physician attire as possible source of nosocomial infections. Am J Infect Control 2011;39(7):555-559

21 Calà C, Amodio E, Di Carlo E, Virruso R, Fasciana T, Giammanco A. Biofilm production in Staphylococcus epidermidis strains, isolated from the skin of hospitalized patients: genetic and phenotypic characteristics. New Microbiol 2015;38(4):521-529

22 Sehulster L, Chinn RY; CDC. HICPAC. Guidelines for environmental infection control in health-care facilities. Recommendations of CDC and the Healthcare Infection Control Practices Advisory Committee (HICPAC) MMWR Recomm Rep 2003;52(RR-10) :1-42 